\title{
Pemanfaatan Media Teknologi Informasi dalam Penyelenggaraan Penyuluhan Perikanan (Kasus Penyuluh Perikanan Kabupaten Tabanan Provinsi Bali)
}

\author{
[The Application of Information Technology Media \\ in Implementing Fisheries Extension Activities \\ (The Case of Fisheries Officers in Tabanan District of Bali Province)] \\ Nila Sylvi Ratnadila, Andin H. Taryoto, Ani Leilani \\ Jurusan Penyuluhan Perikanan, Sekolah Tinggi Perikanan \\ Jl. Cikaret No. 2 Bogor Selatan Kota Bogor
}

\begin{abstract}
Abstrak
Proses pembelajaran adalah salah satu komponen utama dari kegiatan Penyuluhan. Maka penting bagi penyuluh untuk memberikan informasi yang tepat kepada target penyuluh. Teknologi dan informasi adalah dua elemen utama yang mendukung kegiatan penyuluhan. Oleh karena itu, tujuan penelitian ini adalah untuk mengidentifikasi tingkat keterdedahan dinas terkait, penyuluh perikanan dan kelompok sasaran terhadap media teknologi informasi dalam kegiatan perikanan. Penelitian ini pada dasarnya merupakan kualitatif dan deskriptif. Data dan informasi yang dikumpulkan khususnya dengan observasi dan mengisi kuesioner. Lokasi penelitian adalah Kabupaten Tabanan, Bali. Ditemukan bahwa penyuluh perikanan menerapkan media teknologi informasi dalam melaksanakan kegiatan mereka; tiga media utama yang paling banyak digunakan untuk penyuluhan adalah internet, media cetak, dan cyber extension
\end{abstract}

Kata kunci : aktivitas penyuluhan, media penyuluhan, aplikasi teknologi dan informasi

\section{Abstract}

The learning process is one of the main components of Extension activities. It is then important for extension officers to deliver proper information to extension targets. Technology and information are the two main elements that support extension activities. Therefore, the objectives of this research were: (1) to identify the application of information technology by extension officers, targets of extension activities, and related government institutions. The research was a basically qualitative and descriptive one. Data and information were collected mainly by observation and completing questionnaires. The study location was Tabanan district, Bali. It was found that fisheries extension officials applied information technology media in implementing their activities; three main media mostly used by extension officials were internet, printed media, and cyber extension

Keywords: Extension activities, extension media, application of technology and information

Penulis Korespondensi

Nila Sylvi Ratnadila | nila.sylvi17 @gmail.com 


\section{PENDAHULUAN}

Seiring dengan perkembangan teknologi informasi dan multimedia yang begitu cepat, penyuluh perikanan dituntut untuk memahami teknologi informasi dan komunikasi (TIK). Penyuluh juga harus mampu dalam mengaplikasikan teknologi informasi sebelum mereka melakukan kegiatan penyuluhan sehingga mereka mampu menjadi penengah antara pengetahuan dan teknologi yang terus berkembang dan bermanfaat bagi sasaran. Penyuluh perikanan akan membimbing pelaku utama dengan pengetahuan dan teknologi yang sedang berkembang untuk diterapkan kepada sasaran dalam usahanya.

Penyuluh perikanan berperan dalam membantu sasaran menentukan pilihan teknologi yang akan digunakan dengan memberikan pertimbanganpertimbangan atas penggunaan suatu teknologi seperti pertimbangan biaya dan pendapatan, risiko pasar dan saluran pemasaran serta kualitas dan kuantitas produk yang diperlukan konsumen. Agar informasi yang diberikan sesuai dengan yang dibutuhkan oleh sasaran maka penyuluh perlu terus-menerus mengikuti perkembangan ilmu dan teknologi sehingga penyuluh dapat melaksanakan fungsi dan perannya. Perkembangan ilmu dan teknologi tersebut dapat diperoleh salah satunya dengan memanfaatkan berbagai macam media yang tersedia. Informasi yang diperlukan untuk masing-masing penyuluh berbeda tergantung dari masalah spesifik lokasi, kebutuhan informasi sasaran, maupun kondisi dan kebutuhan penyuluh tersebut dalam menunjang pelaksanaan tugas dan pengembangan profesinya. Berdasarkan latar belakang di atas maka tujuan penelitian ini adalah untuk mengidentifikasi tingkat keterdedahan dinas terkait, penyuluh perikanan dan kelompok sasaran terhadap media teknologi informasi dalam kegiatan perikanan.

\section{BAHAN DAN METODE}

Penelitian ini dilakukan pada bulan Februari-April 2019 di Kabupaten Tabanan, Provinsi Bali. Penentuan lokasi penelitian ditentukan secara sengaja dengan pertimbangan bahwa Kabupaten Tabanan merupakan daerah dengan variasi penggunaan TIK dan tingkat aksesibilitas cukup tinggi terhadap sumber informasi, keterdedahan TIK penyuluh cukup tinggi, jaringan internet yang cukup luas, dan terdapat berbagai unit kerja penelitian perikanan dan pusatpusat informasi. Dengan demikian terdapat berbagai pilihan bagi penyuluh perikanan dalam memanfaatkan TIK.

$$
\text { Penelitian ini didisain sebagai }
$$
penelitian survei dengan pendekatan deskriptif kualitatif karena data yang 
terkumpul nantinya akan dianalisis secara kualitatif. Metode deskriptif kualitatif bertujuan untuk menggambarkan, meringkas berbagai kondisi, berbagai situasi atau berbagai fenomena realitas sosial yang ada di masyarakat yang menjadi objek penelitian, dan berupaya menarik realitas itu ke permukaan sebagai suatu ciri, karakter, sifat, model, tanda atau gambaran tentang kondisi, situasi ataupun fenomena tertentu (Bungin 2017). Selain itu menurut Sugiono (2006) dalam Suganda, Sahono, dan Winarni (2013) metode deskriptif bertujuan untuk memahami makna dibalik data yang tampak. Gejala sosial seringkali tidak bisa dipahami berdasarkan apa yang diucapkan dan dilakukan oleh seseorang. Dari beberapa pendapat tersebut maka dalam penelitian ini dilakukan untuk memperoleh informasi tentang bagaimana pemanfaatan teknologi informasi yang tersedia. Adapun alasan pemilihan metode deskriptif kualitatif adalah: 1) metode ini sesuai dengan jenis penelitian yang dilakukan, 2) penelitian ini menuntut peniliti untuk terjun langsung ke lapangan, 3) dengan metode ini peneliti dapat mengungkap semua fenomena dan keadaan serta data yang diperoleh dideskripsikan dengan apa adanya.

Populasi, menurut Bungin (2011) merupakan keseluruhan dari objek penelitian yang dapat berupa manusia, gejala, nilai peristiwa, sikap hidup dan sebagainya, sehingga objek-objek tersebut dapat menjadi sumber data penelitian. Populasi dalam penelitian ini adalah penyuluh perikanan, kelembagaan atau dinas terkait dan kelompok sasaran di Kabupaten Tabanan. Pengumpulan data dilakukan dengan metode snowball sampling. Snowball sampling adalah suatu pendekatan untuk menemukan informaninforman kunci yang memiliki banyak informasi. Dengan menggunakan pendekatan ini, beberapa responden yang potensial dihubungi dan ditanya apakah mereka mengetahui orang yang lain dengan karakteristik seperti yang dimaksud untuk keperluan penelitian. Kegiatan wawancara akan membantu mendapatkan responden lainnya melalui rekomendasi. Untuk mencapai tujuan penelitian, maka teknik ini didukung juga dengan teknik wawancara dan observasi lapangan (Nurdiani 2014).

Metode snowball sampling merupakan suatu metode penarikan sampel yang dalam hal ini responden yang berhasil diperoleh diminta untuk menunjukkan responden-responden lainnya secara berantai. Dalam pelaksanaannya pertama-tama dilakukan interview terhadap suatu kelompok atau seseorang responden yang relevan, dan untuk selanjutnya 
yang bersangkutan diminta untuk menyebutkan atau menunjuk calon responden berikutnya yang memiliki spesifikasi atau spesialisasi yang sama. Tindakan ini ditempuh karena biasanya responden yang merupakan anggota populasi yang spesifik tersebut saling mengenal satu sama lain karena spesialisasi mereka (Sudaryono 2018). Responden yang diambil dalam penelitian ini berjumlah 35 orang dengan spesifikasi 27 orang penyuluh perikanan, 2 orang dari pihak dinas perikanan dan 6 orang pelaku utama perikanan. Namun untuk kegiatan wawancara secara mendalam kepada penyuluh perikanan lebih difokuskan kepada 6 orang responden.

\section{HASIL DAN PEMBAHASAN}

\section{Kegiatan Penyuluhan Berbasis Teknologi Informasi}

Berdasarkan pada hasil penelitian di lapangan, kegiatan penyuluhan terhadap kelompok sasaran dilakukan dengan metode ceramah dan metode demonstrasi. Selain agenda tetap untuk kegiatan penyuluhan yang berjalan biasanya juga disesuaikan dengan kebutuhan dari kelompok sasaran itu sendiri. Hal ini seiring dengan penelitian dari Andriaty, Sankarto, dan Setyorini (2011) yang menyatakan bahwa ketersediaan informasi teknologi di suatu wilayah akan berdampak terhadap tingkat pemenuhan kebutuhan informasi, sehingga penyuluh bisa menyampakan informasi yang berkualitas kepada masyarakat.

Pemanfaatan dari media teknologi informasi telah banyak dimanfaatkan oleh penyuluh perikanan Kabupaten Tabanan dalam menunjang kegiatan penyuluhan yang ada. Dari hasil wawancara dengan penyuluh setempat kebanyakan dari mereka telah mencoba memanfaatkan media teknologi informasi yang mendukung seperti media internet, Cyber Extension maupun media cetak. Motivasi dari penyuluh perikanan untuk memanfaatkan media tersebut adalah untuk mendapatkan informasi terbaru terkait dengan teknologi perikanan yang nantinya informasi tersebut akan diteruskan ke kelompok sasaran pada saat kegiatan penyuluhan perikanan berlangsung. Untuk mengakses informasi seputar perikanan penyuluh perikanan Kabupaten Tabanan lebih sering menggunakan media handphone dan laptop milik pribadi. Penyuluh perikanan lebih sering menggunakan laptop pribadi karena media ini memudahkan mereka untuk dapat menggunakan secara optimal karena tampilan informasinya menjadi lebih jelas. Ketika mereka sedang berada di lapangan, penyuluh akan mulai memanfaatkan smartphone atau handphone yang mereka miliki karena tuntutan untuk menemukan informasi 
yang penting secara cepat dan tepat. Hal tersebut sejalan dengan penelitian Sunarsi dan Dirgahayu (2015) yang menyatakan bahwa pola penggunaan handphone sesuai dengan latar belakang dan status responden, dimana penggunaan handphone dilakukan di rumah, tempat kerja maupun di sekolah. Untuk lebih jelasnya mengenai pemanfaatan dalam kegiatan penyuluhan berbasis teknologi informasi akan dijelaskan sebagai berikut:

\section{Media Internet}

Sesuai dengan pendapat Elian, Lubis, dan Rangkuti (2014) penggunaan media internet oleh penyuluh perikanan yang ada di Kabupaten Tabanan merupakan intensitas akses internet atau gambaran berupa berapa lama dan seberapa sering penyuluh perikanan tersebut menggunakan atau mengakses internet dalam proses pencarian informasi. Berdasarkan hasil wawancara dengan penyuluh perikanan intensitas mereka dalam menggunakan media internet tergolong paling sering dibandingkan dengan media lainnya seperti media cetak maupun Cyber Extension. Namun untuk lama waktu atau frekuensi penggunaanya mereka menggunakan media internet dengan waktu yang relatif singkat. Hal ini dikarenakan penyuluh perikanan memiliki tugas dan tanggung jawab inti untuk melakukan kunjungan ke kelompok-kelompok binaan mereka hampir setiap hari, sehingga tidak memiliki waktu yang banyak untuk mengakses media internet secara intens. Pengukuran frekuensi dalam penelitian ini dilakukan dengan cara mengukur intensitas akses internet yang dilakukan oleh penyuluh perikanan dalam kurun waktu satu minggu. Untuk lebih jelasnya mengenai persentase frekuensi akses internet oleh penyuluh perikanan dapat dilihat pada Tabel 1.

Hasil yang diperoleh pada Tabel 1 menggambarkan bahwa frekuensi mengakses internet dilihat dari beberapa indikator yang meliputi: 1) intensitas akses dalam satu minggu, 2) penggunaan waktu untuk mengakses

Tabel 1. Persentase Frekuensi Akses Internet oleh Penyuluh Perikanan

\begin{tabular}{ccc}
\hline \multirow{2}{*}{ Frekuensi Akses Internet } & \multicolumn{2}{c}{ Responden } \\
\cline { 2 - 3 } & $\mathbf{N}$ (orang) & Persentase (\%) \\
\hline Rendah (Tidak pernah akses internet) & 0 & 0 \\
Sedang (Kadang-kadang) & 23 & 85 \\
Tinggi (Selalu) & 4 & 15 \\
\hline Total & 27 & 100 \\
\hline
\end{tabular}


internet dan 3) media akses internet. Tabel 5 menunjukkan bahwa mayoritas penyuluh perikanan memiliki tingkat frekuensi dengan kategori sedang sebanyak 85 persen dan kategori tinggi 15 persen. Hal tersebut menggambarkan bahwa penyuluh perikanan memiliki ketertarikan terhadap penggunaan internet dan telah mengakses internet secara rutin. Hasil pengukuran frekuensi pada kategori sedang tersebut menunjukkan bahwa intensitas mengakses internet yang dilakukan oleh penyuluh perikanan berkisar antara 1-4 hari dalam kurun waktu satu minggu. Handphone merupakan media yang paling sering digunakan oleh penyuluh perikanan untuk mengakses internet. Mayoritas penyuluh perikanan mengakses internet ketika memiliki waktu luang di malam hari. Penyuluh perikanan yang memiliki tingkat frekuensi akses tinggi adalah penyuluh perikanan yang mengakses internet setiap harinya, rata-rata penyuluh perikanan yang sering mengakses internet adalah penyuluh perikanan berusia muda.
Hasil dari observasi di lapangan menunjukkan bahwa media internet atau jenis layanan yang banyak digunakan oleh penyuluh perikanan untuk memperoleh informasi adalah situs pencarian google. Penyuluh menilai situs ini sangat praktis untuk mendapatkan berbagai informasi yang ingin mereka ketahui. Selain itu situs yang banyak mereka akses adalah situs youtube dimana melalui situs tersebut banyak menampilkan video-video yang inovatif seputar info perikanan yang terbaru. Jenis layanan dalam penelitian ini dikategorikan menjadi tiga kategori yang diukur melalui jenis layanan yang sering digunakan dalam mengakses internet. Untuk jumlah dan persentase jenis layanan yang diakses dalam penggunaan internet dapat dilihat pada Tabel 2.

Tabel 2 memaparkan hasil pengukuran jenis layanan yang diakses oleh responden dalam memanfaatkan internet. Tabel 2 menunjukkan bahwa mayoritas penyuluh perikanan memiliki tingkat kategori sedang yaitu sebesar 52

Tabel 2. Persentase Jenis Layanan yang Diakses Penyuluh Perikanan

\begin{tabular}{ccc}
\hline Jenis Layanan yang Diakses & \multicolumn{2}{c}{ Responden } \\
\cline { 2 - 3 } & N (orang) & Persentase (\%) \\
\hline Rendah (mengakses satu jenis layanan) & 4 & 15 \\
Sedang (mengakses dua jenis layanan) & 14 & 52 \\
Tinggi (mengakses berbagai jenis layanan) & 9 & 33 \\
\hline Total & 27 & 100 \\
\hline
\end{tabular}


persen dalam jenis layanan internet yang diakses. Penyuluh perikanan banyak memanfaatkan layanan google dan youtube untuk mencari informasi berkaitan dengan pekerjaan mereka. Kemudian pada kategori tinggi sebesar 33 persen selain memanfaatkan google dan youtube penyuluh perikanan juga memanfaatkan media sosial dalam seperti whatsapp dan facebook untuk berkaitan dengan pekerjaan maupun untuk hiburan semata. Untuk kategori rendah, yaitu sebesar 15 persen, menggambarkan penyuluh perikanan yang hanya mengakses informasi dari media google saja.

Sebagian besar penyuluh memiliki persepsi bahwa dengan penggunaan media internet memberikan mereka kemudahan untuk mengakses informasi. Penyuluh perikanan berpendapat bahwa informasi yang ada telah sesuai dengan kebutuhan dan kualitas informasi dapat meningkatkan kualitas dari penyuluh itu sendiri. Namun dengan adanya media internet untuk mengakses informasi, penyuluh juga merasa harus selektif ketika akan mengolah suatu informasi dan tidak secara serta merta langsung menerapkan informasi yang mereka peroleh. Berdasarkan dari pengalaman mereka, tidak semua informasi yang ada di media internet bersifat akurat dan benar. Menurut penyuluh perikanan ada beberapa informasi dari internet yang

cenderung dilebih-lebihkan atau terkadang malah bersifat menyebarkan hoax. Hal ini akan menyebabkan kerugian tersendiri bagi penyuluh perikanan maupun sasaran penyuluhan. Informasi yang diakses oleh penyuluh perikanan di internet bukan hanya untuk mereka sendiri, terkadang penyuluh perikanan juga mencari informasi yang dibutuhkan oleh sasaran penyuluhan pada saat itu. Misalnya pada saat pertemuan mingguan, ada seorang pembudidaya yang menanyakan mengenai penanganan hama dan penyakit ikan. penyuluh akan menjawab pertanyaan tersebut berdasarkan pengalaman dan informasi yang pernah ditelusuri di internet, dan menjadikan hal tersebut sebagai bagian dari perumusan programa penyuluhan. Hal tersebut sejalan dengan apa yang diungkapkan oleh IMB (51 tahun):

“Ya internet sendiri
bisa dikatakan media
yang paling
mendukung untuk
proses pencarian
informasi karena berita
yang ada selalu
tergolong up to date.
Namun dalam
mengakses internet
kita juga harus berhati-
hati karena internet
juga punya beberapa
kekurangan yang
salah satunya adalah
berkaitan dengan
informasi yang
disampaikan
cenderung yang baik-


baiknya saja tanpa diimbangi dengan resiko yang ada.

Berkaitan dengan hal tersebut sebelum mengaplikasikan informasi ke pembudidaya diperlukan uji mandiri supaya kita tahu tingkat keberhasilan dari informasi yang kita peroleh melalui internet. Kalau hasilnya memenuhi baru nantinya bisa kita aplikasikan kepada sasaran penyuluhan"

Beberapa keuntungan yang dirasakan oleh penyuluh perikanan dengan memanfaatkan fasilitas internet diantaranya adalah kegiatan penyuluhan dapat disampaikan kapan dan di mana saja, dapat menambahkan beberapa elemen pembelajaran dengan menambahkan unsur komunikasi, materi penyuluhan relatif mudah diperbaharui karena internet banyak menyajikan informasi ter-update, dapat mengembangkan jumlah interaksi diantara penyuluh perikanan dan pelaku utama melalui diskusi interaktif seputar pemanfaatan teknologi informasi, dapat menggunakan sumber yang telah ada di internet untuk kemudian dibuat materi penyuluhan, dapat berhubungan secara real time menggunakan video conference atau video streaming, mempunyai kemampuan untuk mengintegrasikan bermacam unsur media teks, grafik, audio, dan video ke dalam materi ajar. Sejalan dengan penelitian Harahap (2016) yang menyatakan bahwa internet merupakan media pemasok informasi terbesar saat ini. Apa saja informasi yang ingin diketahui dapat dicari melalui media internet. Informasi di masa lampau dan informasi di masa kini semua tersedia di internet.

Pada saat mengakses internet terdapat kendala yang dihadapi oleh penyuluh perikanan khususnya bagi penyuluh yang sudah lanjut usia Penyuluh perikanan yang memiliki usia lebih tua cenderung lebih konvensional dalam mencari informasi seputar perikanan. Kapabilitas dan keterbatasan fisik yang mereka miliki menjadi salah satu hal yang menyebabkan rendahnya frekuensi dan durasi penggunaan internet oleh penyuluh senior. Hal ini tentunya berbeda dengan penyuluh perikanan dengan usia muda, di mana mereka lebih cakap dan lebih melek dalam menggunakan teknologi informasi karena memiliki rasa ingin tahu yang tinggi. Selain itu, tersedianya sarana dan prasarana untuk mengakses informasi yang mendukung maka akan membuat durasi yang semakin tinggi dari penggunaan media internet oleh penyuluh perikanan itu sendiri. 


\section{Cyber Extension}

Menurut Fatimah (2013), Cyber Extension dapat digunakan sebagai media untuk pemanfaatan pelayanan data yang berkaitan dengan informasi penyuluhan yang dibutuhkan oleh penyuluh perikanan di lapangan. Dalam rangka meningkatkan produktivitasnya, beberapa penyuluh menyadari perlunya kapasitas peningkatan pelayanan kerja yang lebih efisien. Mereka menyadari pentingnya penggunaan TIK dalam mendukung kegiatan penyuluhan, namun terkendala pada tingkat pengetahuan dan keterbatasan alat yang menunjang mengingat bantuan dari pusat masih bersifat terbatas karena luasnya medan.

Apabila Cyber Extension dimanfaatkan secara optimal tentunya akan mempermudah tugas dari penyuluh perikanan itu sendiri karena di dalamnya terdapat banyak informasi seputar perikanan. Penyuluh dapat secara bebas mengakses atau mengunggah materi yang ada pada situs Cyber Extension tersebut. Namun berdasarkan hasil wawancara dengan penyuluh perikanan, Cyber Extension ini kurang diminati oleh penyuluh perikanan maupun pelaku utama sebagai sasaran penyuluhan. Menurut mereka Cyber Extension bidang perikanan memiliki banyak kelemahan dan kurang efektif apabila dijadikan sebagai media penyuluhan. Hal ini bertentangan dengan hasil penelitian (Sumardjo, Baga, dan Mulyandari 2010) yang mengatakan bahwa Cyber Extension memiliki peluang menjadi pengembang jaringan komunikasi inovasi yang terprogram secara efektif untuk mempertemukan lembaga penelitian, pengembangan, dan pengkajian dengan diseminator inovasi (penyuluh), pendidik, petani, dan kelompok stakeholders lainnya yang masing-masing memiliki kebutuhan dengan jenis dan bentuk informasi yang berbeda sehingga dapat berperan secara sinergis dan saling melengkapi.

Cyber Extension sendiri tidak dapat dilepaskan dari perkembangan teknologi informasi dan komunikasi namun dalam perkembangannya tidak berbanding lurus dengan perkembangan teknologi dan informasi itu sendiri. Padahal sebagai program penyebarluasan informasi dan teknologi perikanan, akan mencapai sasaran apabila dapat memenuhi kebutuhan dari pengguna khususnya dari penyuluh perikanan itu sendiri, namun penyuluh perikanan beranggapan bahwa Cyber Extension belum memenuhi kriteria tersebut. Hal tersebut hampir sama dengan yang diungkapkan oleh AR (56 tahun):

\footnotetext{
"Kalau Cyber Extension sudah jarang sekali karena untuk sekarang ini sering mengalami
} 


$$
\begin{gathered}
\text { gangguan pada saat } \\
\text { sedang mengakses } \\
\text { dan sepertinya } \\
\text { adminnya juga kurang } \\
\text { responsif, itulah } \\
\text { mengapa membuat } \\
\text { saya jadi malas untuk } \\
\text { membuka lamannya. } \\
\text { Banyak yang } \\
\text { mengeluhkan kalau } \\
\text { Cyber-nya suka down } \\
\text { yang membuat kita } \\
\text { untuk masuknya agak } \\
\text { kesulitan. Kalau } \\
\text { keadaannya sudah } \\
\text { begitu untuk apa juga } \\
\text { saya gunakan lagi" }
\end{gathered}
$$

Beberapa kendala yang lainnya dikeluhkan oleh penyuluh perikanan terkait penggunaan dari Cyber Extension diantaranya adalah manajemen, komitmen dan kebijakan dari Pemerintah Pusat yang dinilai belum konsisten dalam mendukung kesuksesan program Cyber Extension itu sendiri karena minimnya pelatihan berbasis komputer dan akses teknologi informasi untuk penyuluh perikanan yang menyebabkan penyuluh perikanan merasa kurang familiar dalam pemanfaatan Cyber Extension. Di samping itu kemampuan penyuluh perikanan berkaitan dengan manajerial dan operasional di bidang teknologi dan informasi yang masih terbatas menyebabkan penyuluh perikanan kesulitan untuk mempelajari lebih dalam akan manfaat dari Cyber Extension. Hal tersebut sejalan dengan penelitian Nuryanto (2008) yang menyatakan bahwa penyuluh kurang memiliki kemampuan dalam memanfaatkan media dikarenakan kompetensi penyuluh yang relatif masih kurang. Ketidakmampuan penyuluh dalam akses internet menjadi hambatan tersendiri dalam kelancaran akses Cyber Extension. Penyuluh yang kurang mahir dalam mengakses internet berpendapat bahwa mengakses informasi melalui Cyber Extension lebih rumit daripada mendapatkan informasi langsung dari rekan sesama penyuluh maupun atasan. Permasalahan lainnya dalam mengakses Cyber Extension adalah anggapan penyuluh perikanan yang menganggap informasi yang disajikan dalam laman Cyber Extension kurang realistis. Hal tersebut dikarenakan tidak adanya suatu tindakan lebih lanjut tentang keabsahan materi yang telah diunggah sehingga kurang bisa dibuktikan keefektifannya. Hal ini tentunya juga mempengaruhi minat dari penyuluh perikanan yang rendah untuk turut berkontribusi dalam mengunggah materi seputar perikanan kedalam laman Cyber Extension.

Dari realita yang ada mengenai pemanfaatan Cyber Extension oleh penyuluh perikanan Kabupaten Tabanan dapat diketahui bahwa sikap afektif dari penyuluh perikanan terhadap kualitas penggunaan website Cyber Extension adalah kurang berminat akan adanya website tersebut. Hal tersebut 
berdasarkan pada permasalahan yang dihadapi seperti sulitnya website Cyber Extension dioperasikan karena sering mengalami hang dan memakan waktu yang lama untuk masuk ke laman Cyber Extension yang disebabkan oleh gangguan sistem sehingga dinilai tidak efisien penggunaanya oleh penyuluh perikanan Hal tersebut tentunya berdampak pada keberlangsungan kegiatan penyuluhan karena akses Cyber Extension sulit dilakukan dengan cepat, kapan pun dan di mana pun baik menggunakan komputer maupun dengan menggunakan handphone ketika dibutuhkan oleh penyuluh perikanan. $\mathrm{Hal}$ tersebut sesuai dengan penelitian dari Mulyandari (2011) yang menemukan bahwa dalam pelaksanaan Cyber Extension setidaknya terdapat beberapa hambatan, diantaranya adalah manajemen, infrastruktur dan sarana prasarana, keterbatasan SDM dalam aplikasi TIK dan pengetahuan serta rendahnya budaya saling berbagi informasi di media internet.

Berdasarkan hasil wawancara di lapangan untuk ketersediaan dari sarana dan prasarana untuk mengakses Cyber Extension sebenarnya sudah memadai, khususnya untuk sarana pribadi yang berupa ponsel android karena hampir sebagian besar penyuluh perikanan sudah menggunakannya, namun karena kurangnya kemampuan penyuluh dalam mengelola teknologi informasi yang disebabkan faktor-faktor karakteristik seperti latar belakang pendidikan dan dan usia menjadikan minat mereka menjadi rendah terhadap Cyber Extension. Hal ini selaras dengan penelitian Anggoroseto et al (2012) dalam Sumaryo dan Rangga (2017) bahwa kinerja penyuluh dalam memanfaatkan Cyber Extension dipengaruhi oleh faktor-faktor karakteristik seperti latar belakang pendidikan dan usia dari penyuluh. Hasil dari observasi di lapangan menunjukkan penyuluh dengan usia mendekati pensiun jarang mengakses informasi seputar perikanan melalui media internet khususnya Cyber Extension.

\section{Media Cetak}

Media cetak sendiri merupakan alat bantu yang dibuat yang dibuat oleh penyuluh perikanan yang digunakan dalam melakukan kegiatan penyuluhan, karena di dalamnya termuat antara kombinasi huruf (tulisan) dan gambargambar yang dibuat secara tercetak. Untuk jenis media cetak yang digunakan oleh penyuluh perikanan untuk mengakses informasi adalah majalah dan juga koran. Tujuan dari penyuluh membaca koran atau majalah sebagian besar adalah untuk mencari atau mendapatkan informasi, sebagai media pendukung dalam penyuluhan dan 
selebihnya untuk membuat materi penyuluhan dan juga sebagai hiburan. Hal ini menunjukkan bahwa penyuluh membutuhkan waktu yang lebih lama dalam membaca koran khususnya halhal yang berkaitan dengan profesi dan hiburan dengan durasi yang beragam. Sejalan dengan penelitian Veronice (2013) yang menyatakan bahwa pemanfaatan media cetak meliputi koran dan majalah oleh penyuluh perikanan masih tergolong tinggi dibandingkan dengan koran digital. Koran digital masih sangat minim digunakan karena keterbatasan fasilitas dan skill yang mereka miliki khususnya untuk penyuluh yang tergolong memiliki usia lebih senior. Namun informasi tentang kelautan dan perikanan yang didapatkan dari koran masih tergolong minim karena informasi seputar informasi kelautan dan perikanan tidak dapat ditemukan di semua koran atau majalah. Hal tersebut sesuai dengan penelitian Anwas, Asngari, dan Tjitropranoto (2009) yang menyatakan bahwa substansi semua jenis koran yang sering dibaca penyuluh adalah informasi umum. Informasi yang terkait langsung dengan penyuluhan masih kurang. Selain untuk menambah informasi penyuluh perikanan terkadang juga memanfaatkan koran sebagai media untuk kegiatan penyuluhan seperti yang diungkapkan oleh AR (56 tahun):

\author{
"Biasanya untuk \\ sasaran penyuluhan \\ yang tua-tua kita \\ melakukan \\ penyuluhan dengan \\ pendekatan personal. \\ Biasanya saya \\ bawakan koran \\ sewaktu kunjungan ke \\ kelompok baru setelah \\ itu akan muncul \\ diskusi dengan \\ mereka, apalagi kalau \\ materinya cocok atau \\ sesuai dengan \\ kebutuhan mereka, \\ sudah bisa dipastikan \\ sesi diskusinya juga \\ akan berjalan dengan \\ maksimal. Koran yang \\ tadi saya bawa selalu \\ saya berikan ke \\ sasaran saya namun \\ untuk kelanjutannya \\ apakah akan dibaca \\ atau tidak oleh mereka \\ itu kembali lagi ke \\ kebutuhan masing \\ masing".
}

Menurut hasil wawancara dengan salah seorang penyuluh untuk jenis koran yang sering dibaca oleh penyuluh perikanan adalah koran tingkat provinsi yaitu Manggala yang terbit setiap seminggu sekali. Koran tersebut selain memuat informasi seputar berita-berita up to date yang terjadi di Provinsi Bali juga banyak memuat informasi seputar perikanan khususnya di Kabupaten Tabanan itu sendiri. Hal tersebut dikarenakan ada beberapa orang penyuluh perikanan yang turut berkontribusi dalam menuangkan 
pemikiran dan inovasinya melalui tulisan untuk koran Manggala tersebut. Tulisan yang penyuluh perikanan bagikan biasanya mengenai teknik budidaya, pengendalian hama penyakit dan mengenai berbagai komoditas ikan yang potensial di Provinsi Bali. Selain itu kegiatan penyuluhan yang telah mereka lakukan biasanya akan mereka tuangkan hasilnya dalam sebuah artikel yang selanjutnya akan dimuat dalam koran. Namun tidak semua penyuluh mengakses informasi dari koran maupun majalah, khususnya untuk penyuluh yang tergolong masih muda karena mereka menganggap hal tersebut kurang praktis ditengah era digital seperti sekarang yang segala hal dapat diakses melalui media internet. Hal tersebut diakui sendiri oleh LAS (30 tahun)

\footnotetext{
"Jadi kalau sekarang kan teknologinya sudah maju ya, jadi untuk apa-apanya tidak harus mencari buku karena menurut saya pribadi hal itu malah membuangbuang waktu. Makanya apa-apa sekarang lebih suka dari internet saja. Nanti juga sewaktu proses penyuluhan selain memberikan informasi kita juga sarankan ke sasaran untuk selalu update informasi dari internet. Cuma sekarang kan
}

\author{
banyak pelaku utama \\ yang sudah tua jadi \\ banyak dari mereka \\ yang gaptek jadinya \\ untuk \\ penyampaiannya lebih \\ ke diskusi saja"
}

Selain memanfaatkan koran dan majalah sebagai media pencarian informasi, berdasarkan hasil wawancara di lapangan penyuluh juga memanfaatkan media cetak lain berupa buku-buku perikanan yang di dalamnya memuat berbagai penelitian ilmiah. Penyuluh perikanan menganggap dengan adanya penelitian ilmiah yang telah dimuat dalam buku-buku tersebut akan memberikan tingkat keefektifan suatu informasi menjadi lebih tinggi dan terpercaya karena telah dilakukan uji coba sebelumnya. Berdasarkan informasi dari penyuluh perikanan hasil penelitian perikanan yang langsung diaplikasikan adalah sesuatu yang keliru. Penelitian ilmiah sendiri harus dibuat terlebih dahulu aplikasi dari penelitiannya, kemudian aplikasi dari penelitian tersebut harus direkayasa ilmunya untuk melihat bagaimana peluangnya. Dibandingkan dengan bukubuku ilmiah perikanan populer, bukubuku yang sifatnya murni ilmiah seperti hasil ilmiah atau hasil perekayasaan akan lebih akurat dari sisi informasi dan penerapannya karena ditulis berdasarkan realitas yang ada. Melihat 
kondisi tersebut dengan pemanfaatan buku-buku penelitian ilmiah tentunya akan semakin memaksimalkan kemampuan penyuluh perikanan dalam mengolah dan mengembangkan informasi seputar perikanan.

\section{SIMPULAN DAN SARAN}

Dalam melakukan aktivitas yang berkaitan dengan penyelenggaraan penyuluhan perikanan berbasis teknologi dan informasi, penyuluh perikanan banyak mengakses informasi melalui media internet dan media cetak. Untuk penggunaan Cyber Extension sangat minim karena dinilai banyak memiliki kekurangan. Dalam pelaksanaannya penyuluh perikanan melakukan kegiatan penyuluhan perikanan dengan diskusi dan demonstrasi kepada sasaran. Setelah adanya kegiatan penyuluhan, sasaran penyuluhan banyak merasakan manfaat dari adanya teknologi informasi dan tidak sedikit dari mereka yang menerapkannya dalam kegiatan yang mereka lakukan.

Saran yang dapat diberikan dalam penelitian ini adalah pemerintah khususnya dari Kementerian Kelautan dan Perikanan perlu mengadakan pelatihan-pelatihan yang sifatnya lebih intensif kepada penyuluh perikanan dalam hal akses teknologi dan informasi. Pelatihan tersebut khususnya ditujukan untuk penyuluh perikanan yang telah memiliki usia lanjut mengingat kebanyakan penyuluh perikanan yang memiliki usia lanjut sangat minim dalam memanfaatkan media teknologi informasi yang sifatnya lebih modern seperti media internet. Hal ini dimaksudkan agar kemampuan mereka meningkat dan akan meningkatkan kompetensinya sebagai penyuluh perikanan.

\section{PERSANTUNAN}

Dalam penyusunan laporan penelitian ini tidak lepas dari bantuan dan dukungan berbagai pihak. Maka dari itu penulis mengucapkan terima kasih kepada Dr. Andin H. Taryoto dan Dra. Ani Leilani, M.Si karena telah banyak membantu dan memberikan bimbingannya dalam penelitian ini sehingga dapat terselenggara dengan lancar. Penulis juga mengucapkan terima kasih kepada Dinas Perikanan Kabupaten Tabanan sebagai fasilitator dalam penelitian ini serta pihak-pihak terkait yang telah banyak berkontribusi dalam penelitian ini.

\section{DAFTAR PUSTAKA}

Andriaty, Etty, Bambang S. Sankarto, dan Endang Setyorini. 2011. "Kajian kebutuhan informasi teknologi pertanian di beberapa kabupaten di Jawa." Jurnal Perpustakaan Pertanian 20(2):54-61. 
Anwas, E. O. M., P. S. Asngari, dan P. Tjitropranoto. 2009. "Faktor-faktor yang mempengaruhi penyuluh dalam pemanfaatan media." Jurnal Komunikasi Pembangunan 7(2).

Bungin, Burhan. 2011. Metodologi Penelitian Kuantitatif. Jakarta (ID): Kencana.

Bungin, Burhan. 2017. Penelitian Kualitatif: Komunikasi, Ekonomi, Kebijakan Publik dan IImu Sosial Lainnya. Jakarta (ID): Kencana.

Elian, Novi, Djuara P. Lubis, dan Parlaungan A. Rangkuti. 2014. "Internet Ussage and Agricultural Information Utilization by Agricultural Extension Staff in Bogor District." Jurnal KMP (Jurnal Komunikasi Pembangunan) 12(2):104-12.

Fatimah, Sri. 2013. "Menuju sumberdaya penyuluhan pertanian tanggap perubahan: Kasus implementasi cyber extension di Kabupaten Sumedang." Hal. 196-205 in Prosiding Seminar Nasional Peranan Teknologi dan Kelembagaan Pertanian dalam Mewujudkan Pembangunan Pertanian yang Tangguh dan Berkelanjutan.

Harahap, Abdul Rahman. 2016. "Pemanfaatan Teknologi Informasi dan Komunikasi dalam Pemenuhan
Informasi bagi Rumah Tangga Usaha Pertanian di Kecamatan Halongonan Kabupaten Padang Lawas Utara." Jurnal Penelitian Komunikasi dan Pembangunan 17(2).

Mulyandari, Retno Sri Hartati. 2011. "Cyber Extension Sebagai Media Komunikasi Bagi Pemberdaya Petani Sayuran [Disertasi]." Institut Pertanian Bogor.

Nurdiani, Nina. 2014. "Teknik sampling snowball dalam penelitian lapangan." ComTech: Computer, Mathematics and Engineering Applications 5(2):1110-18.

Nuryanto, Bambang Gatut. 2008. "Kompetensi Penyuluh dalam Pembangunan Pertanian di Provinsi Jawa Barat [Disertasi]." Institut Pertanian Bogor.

Sudaryono. 2018. Metodologi Penelitian. Depok (ID): Rajawali Pers.

Suganda, Romi, Bambang Sahono, dan Endang Widi Winarni. 2013. "Pengelolaan Sarana Pembelajaran Bahasa Inggris (Studi Deskriptif Kualitatif di SMP Negeri 20 Bengkulu Selatan)." Universitas Bengkulu.

Sumardjo, Lukman Mohammad Baga, dan Retno Sri Hartati Mulyandari. 2010. Cyber extension: peluang dan tantangannya dalam revitalisasi 
penyuluhan pertanian. Bogor (ID):

IPB Press.

Sumaryo dan Kordiyana K. Rangga.

2017. "Implementasi Cyber

Extension Dalam Pengembangan

Sumberdaya Manusia Pertanian:

Kendala yang Dihadapi di Provinsi

Lampung." Hal. 295-307 in

Prosiding Seminar Nasional

Darmajaya. Lampung (ID):

Universitas Darmajaya.

Sunarsi, Risa dan Dida Dirgahayu. 2015.

"Pemanfaatan Handphone Pada

Masyarakat Pedesaan Di Desa

Sukataris Kabupaten Cianjur."

Jurnal Penelitian Komunikasi dan

Opini Publik 19(1):57-67.

Veronice. 2013. "Pemanfaatan Teknologi

Informasi dan Komunikasi dalam

Peningkatan Kompetensi Penyuluh

[Tesis]." Institut Pertanian Bogor. 